\title{
Effects of a high-energy diet on oocyte quality and in vitro embryo production in Bos indicus and Bos taurus cows
}

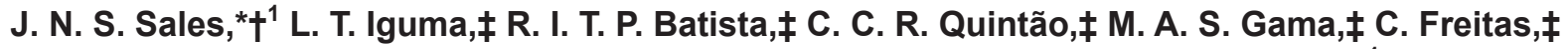 \\ M. M. Pereira, $\ddagger$ L. S. A. Camargo, $\ddagger$ J. H. M. Viana, $\ddagger$ J. C. Souza, $†$ and P. S. Baruselli ${ }^{11}$ \\ *Department of Animal Reproduction, Faculdade de Medicina Veterinaria e Zootecnia, Universidade de São Paulo (FMVZ-USP), \\ Rua Prof. Orlando Marques de Paiva, 87, 05508-000 São Paulo, SP, Brazil \\ †Department of Veterinary Medicine, Departamento de Medicina Veterinaria (DMV), Universidade Federal de Lavras, 37200-000, \\ Lavras, MG, Brazil \\ ‡EMBRAPA Gado de Leite, 36038-330 Juiz de Fora, MG, Brazil
}

\section{ABSTRACT}

The effects of different dietary energy levels [100 and $170 \%$ for maintenance $(\mathrm{M})$ and high energy (1.7M), respectively] on metabolic, endocrine, and reproductive parameters were evaluated in nonlactating Bos indicus (Gir; $\mathrm{n}=14$ ) and Bos taurus (Holstein; $\mathrm{n}=14$ ) cows submitted to ultrasound-guided ovum pick-up followed by in vitro embryo production. The oocyte donor cows were housed in a tiestall system and fed twice daily (0800 and $1600 \mathrm{~h}$ ). Twenty-one days before the beginning of the experiment, the animals were fed with a maintenance diet for adaptation followed by the experimental diets ( $\mathrm{M}$ and $1.7 \mathrm{M}$ ), and each cow underwent 9 ovum pick-up procedures $14 \mathrm{~d}$ apart. The recovered oocytes were cultured in vitro for $7 \mathrm{~d}$. We measured glucose and insulin concentrations and performed glucose tolerance tests and the relative quantification of transcripts (PRDX1, HSP70.1, GLUT1, GLUT5, IGF1R, and $I G F 2 R)$ from the oocytes recovered at the end of the experimental period. No interactions were observed between the effects of genetic groups and dietary energy level on the qualitative (viable oocytes, quality grade, and oocyte quality index) and quantitative (oocytes recovered) oocyte variables. There were no effects of dietary energy level on the qualitative and quantitative oocyte variables. However, Bos indicus cows had greater numbers of recovered structures, viable oocytes, and A and B oocyte grades as well as better oocyte quality index scores and lower DNA fragmentation rates compared with Bos taurus donors. In vitro embryo production (cleavage and blastocyst rates and number of embryos) was similar between diets, but the $1.7 \mathrm{M}$ diet reduced in vitro embryo production in Bos indicus cows after $60 \mathrm{~d}$ of treatment. Moreover, Bos indicus cows on

\footnotetext{
Received September 15, 2014.

Accepted December 3, 2014.

${ }^{1}$ Corresponding authors: znlogan@yahoo.com.br and barusell@usp.
} br the $1.7 \mathrm{M}$ diet showed lower transcript abundance for the HSP70.1, GLUT1, IGF1R, and IGF2R genes. All cows fed 1.7M diets had greater glucose and insulin concentrations and greater insulin resistance according to the glucose tolerance test. In conclusion, increasing dietary energy did not interfere with oocyte numbers and quality, but the 1.7M diet reduced in vitro embryo production in Bos indicus cows after $60 \mathrm{~d}$ of treatment. Finally, Bos indicus cows had greater oocyte quality, greater numbers of viable oocytes and greater in vitro embryo yield than Bos taurus.

Key words: bovine, nutrition, oocyte, ovum pickup-in vitro production, cattle

\section{INTRODUCTION}

Various studies have demonstrated a relationship between nutrition and reproduction (Garnsworthy et al. 2008; Sales et al., 2011; Thatcher et al., 2011), but this relationship is extremely complex. Nutritional factors may act on many levels of the ovarian-hypothalamushypophyseal axis, which may be directly reflected in reproductive efficiency (Leroy et al., 2008). Additionally, acute or chronic changes in the nutritional plane or body condition may alter the release and synthesis of reproductive and metabolic hormones, oocyte quality, and follicular growth (Armstrong et al., 2003). Such alterations may promote an imbalance in the circulating concentrations of some metabolites and hormones linked to animal metabolism (insulin, IGF-1, and leptin; Adamiak et al., 2005). Some authors report that animals used in reproductive biotechnologies that are submitted to diets in excess of their maintenance requirements undergo lower than average yields and reproductive problems (Santos et al., 2008), such as reduced viable oocyte numbers and blastocyst rates (Adamiak et al., 2005).

It is common for growing heifers and show-ring cows to be fed diets in excess of their nutritional requirements for maintenance and growth, but these exces- 
sively high nutritional planes are often reported as being detrimental to fertility (Armstrong et al., 2001). Additionally, the effects of high-plane feeding on fertility may be chronically present throughout the lives of these cows (Adamiak et al., 2005). The literature normally expresses high nutritional planes as multiples of the energy required for body maintenance, and they vary between 1.6 and 2.0 times maintenance requirements (Armstrong et al., 2001; Adamiak et al., 2005). Such values are usually sufficient to induce obesity in cows and heifers.

It is important to clarify that most of the scientific data on the effects of higher nutritional planes on fertility originate from studies of cross-bred cattle (Armstrong et al., 2001; Wrenzycki et al., 2001; Adamiak et al., 2005). Therefore, it would be of interest to evaluate the effects of excess diet energy in Bos indicus and Bos taurus cows kept under similar management conditions because aspects of the reproductive physiology these 2 genetic types, such as estrus behavior, steroid hormone concentrations, follicular development, and postpartum reproduction characteristics, are distinct (Sartori et al., 2010). Moreover, most studies evaluate the acute effects of increased dietary energy on fertility (Leroy et al., 2008), so a need to study the chronic effects exists.

In determining the different effects of nutrition on reproduction in Bos indicus and Bos taurus, we hypothesized that cows from both genetic groups that were subjected to a high-energy diet for a long period would have compromised oocyte quality and in vitro embryo production. An additional hypothesis was that Bos indicus donors have superior quality oocytes and produce more in vitro embryos than Bos taurus donors. Thus, the objective of our study was to evaluate the effect of dietary energy levels on oocyte quality and on in vitro embryo production in nonlactating Bos indicus and Bos taurus cows.

\section{MATERIALS AND METHODS}

\section{Study Animals and Handling Procedures}

The experiment was conducted at the EMBRAPA Santa Mônica research unit in Valença (RJ, Brazil) from July to November 2009. Twenty-eight multiparous, nonlactating cows were used (14 Gir and 14 Holstein, Bos taurus and Bos indicus, respectively). The average BCS was $3.22 \pm 0.38$ (range $=2.75-3.75)$ according to the scoring system by Wildman et al. (1982), and the average age and BW were $5.21 \pm 0.56 \mathrm{yr}$ of age and $487.8 \pm 36.6 \mathrm{~kg}(440-570 \mathrm{~kg})$, respectively. Animals were kept in a tiestall barn and diets were offered twice a day (0800 and $1600 \mathrm{~h}$ ), which allowed for the evalua- tion of individual feed intakes. Cows were released into an adjacent dry lot with free access to water at night $(2300 \mathrm{~h})$. The study was performed during the winter and spring, and ambient temperature and humidity were, respectively, $20.1^{\circ} \mathrm{C}$ and $84.7 \%$ in the morning $(0800 \mathrm{~h}), 25.4^{\circ} \mathrm{C}$ and $64.2 \%$ in the afternoon $(1600 \mathrm{~h})$, and $19.7^{\circ} \mathrm{C}$ and $87.1 \%$ at night $(2300 \mathrm{~h})$.

\section{Experimental Design}

The trial was conducted in 3 stages: pre-experimental, adaptive, and experimental (Figure 1). During the pre-experimental period, animals were allowed to adapt to the tiestall for $30 \mathrm{~d}$ and were fed a urea-sugar cane-based diet ad libitum. During this period, 3 ultrasonographic exams were performed (at 10-d intervals) to establish the ovarian antral follicular count (AFC) and to balance this variable between treatments and minimize possible donor effects. During the adaptation period, all cows were fed a maintenance diet for $21 \mathrm{~d}$. Then, Bos indicus and Bos taurus cows were blocked by AFC, BW, and BCS and assigned to 1 of 2 diets in a $2 \times 2$ factorial design: 100 [maintenance $(\mathbf{M})$ ] and $170 \%$ [high energy $(\mathbf{1 . 7 M})$ ] of the maintenance energy requirements according to the NRC (2001).

As nutritional requirements for Gir cows are still not fully established, diets were formulated using SPARTAN (Michigan State University, East Lansing) software according to the requirements established for Holstein cows as estimated by the NRC (2001). Therefore, similar diets were provided for both genetic groups. The proportion of the dietary ingredients and the predicted chemical composition of the diets are shown in Table 1 . The only difference between the diets was the amount of energy; intakes of protein and the primary macro- and micronutrients were similar. Diets were adjusted for individual BW changes every $15 \mathrm{~d}$.

\section{Ultrasound-Guided Transvaginal Follicular Aspiration}

Animals were submitted to 9 ovum pick-up (OPU) sessions at 14-d intervals. Synchronization of the follicular wave was done $5 \mathrm{~d}$ before the OPU sessions with a 2-mg injection of estradiol benzoate (Sincrodiol, Ourofino Agronegócio) and a norgestomet ear implant (Crestar, Intervet Schering-Plough Animal Health).

An $8.0-\mathrm{MHz}$ convex ultrasound probe (Aquila, Pie Medical, Maastricht, the Netherlands) and an $80-\mathrm{cm}$ aspiration line coupled to a 20-gauge disposable needle (WTA, Cravinhos, SP, Brazil) were used for the OPU sessions. Before the OPU, the AFC was recorded for each ovary. The aspiration system was submitted to 


\section{MAINTENANCE DIET}

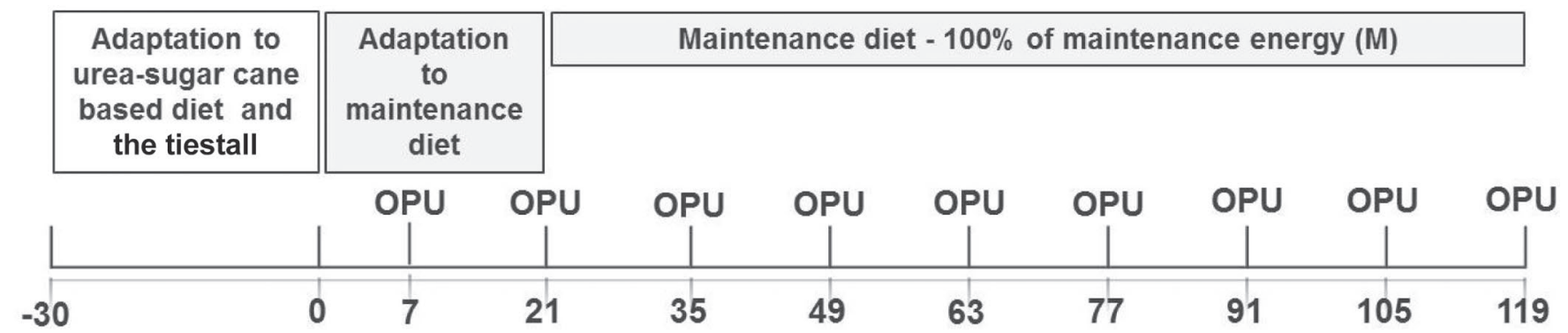

\section{HIGH ENERGY DIET}

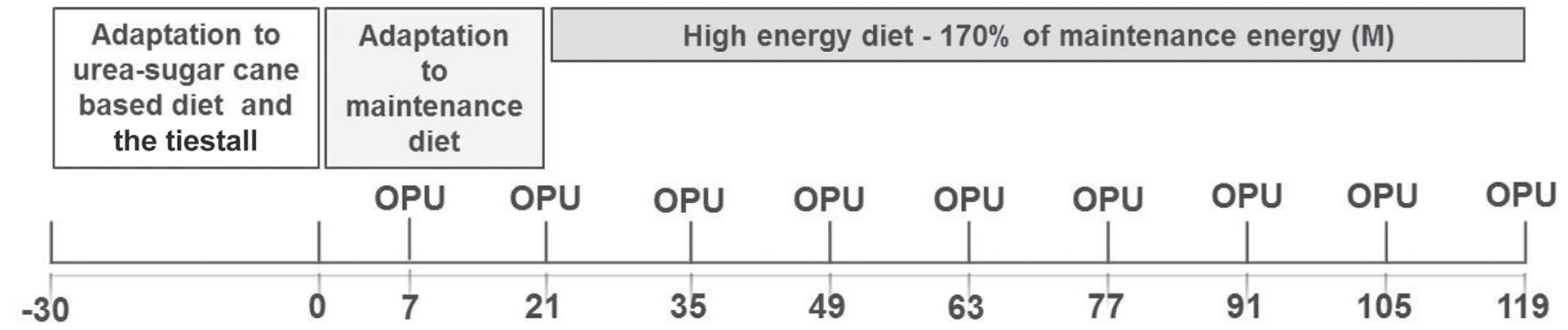

Figure 1. Experimental design of the different phases of the trial and ovum pick-up (OPU) for in vitro embryo production.

negative pressure of between 10 and $15 \mathrm{~mL}$ of medium/minute $(60-70 \mathrm{mmHg})$ through a vacuum pump (WTA). All visible follicles $(>3 \mathrm{~mm})$ were punctured, and the contents were collected in a $50-\mathrm{mL}$ plastic tube (TPP, Trasadingen, Suíça) that previously contained $10 \mathrm{~mL}$ of $1 \%$ fetal calf serum Dulbecco's modified phosphate-buffered saline (DMPBS) added to $125 \mathrm{IU}$ of sodium heparin/mL (Liquemine, Roche, São Paulo, SP, Brazil) and kept between 35 and $36^{\circ} \mathrm{C}$. The plastic tube containing the aspirated liquid was poured into an 80$\mu \mathrm{m}$ mesh filter (WTA). Next, the filtered content was transferred to $100-\times 20$-mm cell culture-specific Petri dishes (TPP) containing DMPBS and was searched under a stereomicroscope (Olympus, SZ40, Center Valley, PA) for cumulus-oocyte complexes (COC). The COC were evaluated according to Leibfried and First (1979).

\section{In Vitro Oocyte Maturation, Fertilization, and Culture}

The COC were matured in vitro in cryotubes (a maximum of 30 structures per tube) for 22 to $24 \mathrm{~h}$. Maturation was performed in tissue culture medium (TCM-199; Gibco Life Technologies, Grand Island, NY) supplemented with $20 \mathrm{mg} / \mathrm{mL}$ of FSH (Pluset, Serono, Italy), $0.36 \mathrm{~m} M$ sodium pyruvate, $10 \mathrm{~m} M$ sodium bicarbonate, and $50 \mathrm{mg} / \mathrm{mL}$ of streptomycin-penicillin in a $95 \%$ humidified atmosphere of $5 \% \mathrm{CO}_{2}$ at $38.5^{\circ} \mathrm{C}$. After the in vitro maturation, the selected $\mathrm{COC}$ were fertilized with frozen-thawed semen $(0.25-\mathrm{mL}$ straws) from a single batch of a Holstein sire of proven in vitro fertility. In vitro fertilization was performed by adding $100 \mu \mathrm{L}$ of Fert-TALP droplets to $10 \mathrm{IU} / \mathrm{mL}$ of heparin and covering the solution with mineral oil (Sigma Aldrich, St. Louis, MO; Gordon, 2004), the concentration was adjusted to $2 \times 10^{6}$ spermatozoa/mL and kept in the fertilization medium drop with the oocytes for 18 to $20 \mathrm{~h}$. Presumed zygotes were cocultured with autologous cumulus cells (denuded by repetitive pipetting) in $5 \%$ fetal calf serum in modified synthetic oviduct fluid medium in $50 \mu \mathrm{L}$ mineral oil-covered droplets under $5 \%$ $\mathrm{CO}_{2}, 5 \% \mathrm{O}_{2}$, and $90 \% \mathrm{~N}_{2}$ at $38.5^{\circ} \mathrm{C}$. The evaluation of cleavage rate and $50 \%$ medium replacement (feeding) were performed $72 \mathrm{~h}$ postfertilization. Blastocyst rates were evaluated $192 \mathrm{~h}$ postfertilization. Groups of 15 to 30 oocytes were cultured per droplet of medium.

\section{BCS, BW, and Rump Fat Thickness}

Evaluations of BCS, BW, and rump fat thickness (RFAT) were performed on the next day following the 
Table 1. Ingredients and chemical composition of the diet to meet 100 (maintenance) or $170 \%$ (high energy) of the energy required for maintenance

\begin{tabular}{lcc}
\hline Item & & $\begin{array}{c}\text { High } \\
\text { energy }\end{array}$ \\
\hline Ingredient (\% of DM) & Maintenance & \\
Sugarcane & & \\
Corn meal & 0.4 & 39.3 \\
Soybean meal & 19.5 & 43.4 \\
Urea & 1.9 & 12.3 \\
Limestone & 0.1 & 0.9 \\
Vitamin-mineral premix ${ }^{1}$ & 2.1 & 0.2 \\
Sodium bicarbonate & 0.0 & 2.4 \\
Magnesium oxide & 0.0 & 1.1 \\
Chemical composition (\% of DM) & & 0.4 \\
CP & 15.8 & 12.0 \\
NDF & 41.8 & 26.3 \\
ADF & 26.9 & 15.4 \\
Ether extract & 1.4 & 2.7 \\
TDN & 62.2 & 71.4 \\
Predicted daily intake ${ }^{2}$ & & \\
DM (kg) & 8.1 & 11.6 \\
CP (kg) & 1.3 & 1.4 \\
NE ${ }_{\mathrm{L}}^{3}$ (Mcal) & 11.0 & 18.8 \\
\hline
\end{tabular}

${ }^{1}$ Mineral vitamin premix: $0.6 \%$; phosphorus, $0.3 \%$; cobalt, $0.002 \%$; copper, $0.021 \%$; sulfur, $0.06 \%$; iron, $0.006 \%$; iodine, $0.001 \%$; magnesium, $0.15 \%$; manganese, $0.003 \%$; selenium, $0.0003 \%$; sodium, $0.3 \%$; zinc $0.011 \%$; chlorine, $0.2 \%$; fluorine, $0.003 \%$; vitamin A, 100,000 IU/ $\mathrm{kg}$, vitamin $\mathrm{E}, 1,000 \mathrm{IU} / \mathrm{kg}$; vitamin $\mathrm{D}, 30,000$.

${ }^{2}$ Estimated by SPARTAN software (Michigan State University, East Lansing).

${ }^{3}$ Calculated from model in NRC (2001); these values were used in calculation of energy intakes.

OPU session before the first daily feeding $(0800 \mathrm{~h})$. Rump fat thickness was measured at the Biceps femoris (RFTP8) by ultrasound with a $3.5-\mathrm{MHz}$ and $17.8-\mathrm{cm}$ linear probe (Scanner 200 VET, Pie Medical) according to Wilson (1992).

\section{Blood Samples and Glucose and Insulin Analysis}

Blood samples were taken every $14 \mathrm{~d}$ by coccygeal venipuncture (Vacutainer, Becton, Dickinson and Company, Fair Lawn, NJ) for glucose (sodium fluoride tube) and for insulin (glass tube without additives). Plasma and serum were separated by centrifugation at 2012 $\times g$ at room temperature for $10 \mathrm{~min}$ and stored in a $-21^{\circ} \mathrm{C}$ freezer.

Glucose concentration was analyzed according to Trinder (1969) and expressed in milligrams per deciliter. Serum insulin was determined by solid phase RIA using a commercial kit (Coat-a-Count Insulin, DPC Diagnostic Products Inc., Los Angeles, CA) previously validated for bovine (Reimers et al., 1982). Intra- and interassay coefficients of variation were 5.79 and $8.93 \%$, respectively, and the test sensitivity was $0.36 \mu \mathrm{IU} / \mathrm{mL}$. The results were expressed in microinternational units per milliliter.

\section{Glucose Tolerance Test}

The glucose tolerance test (GTT) was performed 102 $\mathrm{d}$ after the initiation of the treatments to determine the insulin profile over $120 \mathrm{~min}$. On the day before the test, a flexible 18-gauge catheter (BD Angiocath, Becton, Dickinson and Company) was fixed into the jugular vein of the donors. The GTT was initiated $5 \mathrm{~h}$ after diets were offered according to Adamiak et al. (2005). Three blood samples were collected at 10-min intervals $(-20,-10$, and $0 \mathrm{~min})$ before the glucose infusion to establish the basal concentration of glucose and insulin. Animals received an intravenous bolus of a $0.3 \mathrm{~g} / \mathrm{kg}$ of glucose solution [glucose $50 \%$ (wt/vol)] over $5 \mathrm{~min}$ followed by blood sampling at 5, 10, 20, 30, 40, 60, 80, 100, and $120 \mathrm{~min}$. All samples were collected in 4-mL sodium chloride vacuum tubes (Vacutainer, Becton, Dickinson and Company). The same manipulation and storage procedures described in the Blood Samples and Glucose and Insulin Analyses section for glucose and insulin were applied. The GTT was used to calculate the metabolic rate $(k)$ and the plasma glucose half-life $\left(T^{1 / 2}\right)$. The $k$ value was calculated by the formula, $k=$ $\{[\ln$ (glucose) T10 - ln (glucose) T40]/[T40 - T10] $\times$ 100 , where T10 is the glucose concentration 10 min after administration bolus of glucose and T40 is the glucose concentration 40 min after administration bolus of glucose, according to Opsomer et al. (1999). The glucose half-life was then calculated as $T^{1 / 2}=(0.693 / k) \times 100$. The insulin response induced by the administration of glucose was evaluated with the insulin concentration peak and the incremental change in insulin [(insulin) peak - basal (insulin); $\Delta \mathrm{Max}$ ] (insulin concentration peak over the baseline level).

\section{Oocyte Transcript Quantification}

Total RNA Extraction and Reverse Transcription. The oocytes used for the analysis of gene expression were obtained from the OPU performed at the end of the experimental period (d 133). The OPU was preceded by the synchronization of the follicular wave, and the methods used for COC manipulation were the same as described in section UltrasoundGuided Transvaginal Follicular Aspiration. Oocytes were rapidly frozen in liquid nitrogen after being denuded. Total RNA was extracted from 3 pools of 10 oocytes (grades A and B) per group using the RNeasy Micro Kit (Qiagen, Hilden, Germany), according to the manufacturer's instructions, and treated with DNase. The RNA samples were reverse transcribed using the SuperScript III First-Strand Synthesis Supermix (Invitrogen, Carlsbad, CA) according to the manufacturer's instructions. Quantification of RNA and cDNA from 
Table 2. Primer sequences used for relative gene expression analysis by real-time polymerase chain reaction

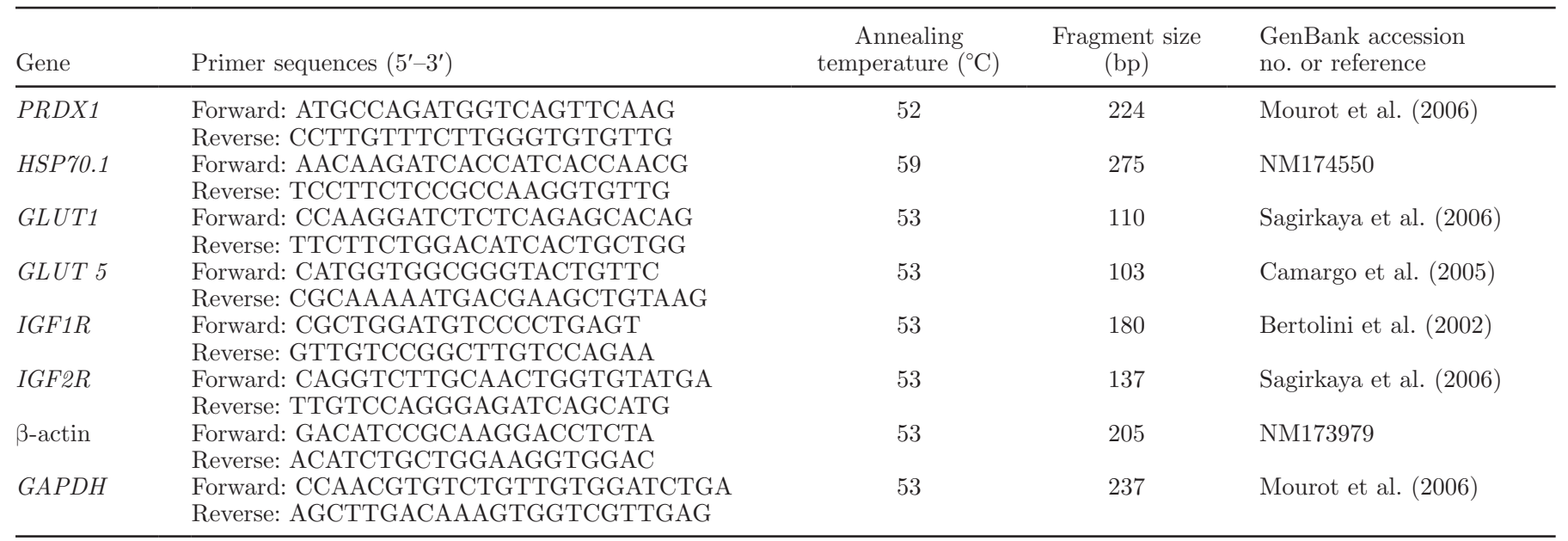

each pool per group was performed using a 1- $\mu \mathrm{L}$ sample in a spectrophotometer (Nanodrop, Wilmington, DE).

Relative Quantification by Real-Time PCR. Relative quantification was performed in triplicate by real-time PCR (ABI Prism 7300 Sequence Detection Systems, Foster City, CA). Reactions were prepared using a mixture of SYBR Green PCR Master Mix (Applied Biosystems), primers, nuclease-free water, and cDNA. The amount of cDNA used in the reactions varied according to the optimal concentration identified in the preliminary experiments for each transcript analyzed. For the PRDX1 and HSP70.1 genes, $600 \mathrm{ng}$ of cDNA per reaction were used, whereas for the GLUT1, GLUT5, IGF1R, IGF2R, GAPDH, and $\beta$-actin genes, $400 \mathrm{ng}$ of cDNA were used per reaction. The cDNA template was denatured at $95^{\circ} \mathrm{C}$ for $10 \mathrm{~min}$ followed by 45 cycles at $95^{\circ} \mathrm{C}$ for $15 \mathrm{~s}$. Next, the template was subjected to $30 \mathrm{~s}$ at the gene-specific primer annealing temperature (Table 2) followed by elongation at $60^{\circ} \mathrm{C}$ for $30 \mathrm{~s}$. After each PCR run, a melting curve analysis was performed to confirm that a single, specific product had been generated. Negative controls, which were the $\mathrm{PCR}$ reaction mixture without nucleic acids, were also run along with each group of samples. Primer efficiency was calculated for each reaction using LinRegPCR software (Ramakers at al., 2003), and the $\beta$-actin gene was used as an endogenous control. The GLUT1, GLUT5, $I G F 1 R$, and IGF2R genes are related to cellular metabolism through their action on glucose transport, which is modulated by the circulating concentration of insulin (Andersen et al., 1992; Schäffer, 1994; Wilson et al., 1995). The PRDX1 and HSPr0.1 genes act on the cellular defense mechanism under situations of oxidative or thermal stress (Niemann and Wrenzycki, 2000; Kawarsky and King 2001; Leyens et al., 2004).
Evaluation of DNA Fragmentation. The follicular punction used for the TUNEL (terminal deoxynucleotidyl transferase mediated dUTP nick end labeling) assay was performed $7 \mathrm{~d}$ after the last OPU in the in vitro production trial, and the OPU and COC manipulation methods were similar to those described in the Ultrasound-Guided Transvaginal Follicular Aspiration section. All oocytes (grades A and B) were separated from the cumulus cells by the hyaluronidase $(0.1 \%)$ associated with vortexing. Next, oocytes were washed 3 times in a $0.1 \%$ polyvinyl pyrrolidone solution in PBS and fixed in $4 \%$ paraphormoldehyde for $1 \mathrm{~h}$ at room temperature. Oocytes were then washed again in PBS-polyvinyl pyrrolidone solution and maintained in $400 \mu \mathrm{L}$ of this solution between 4 and $8^{\circ} \mathrm{C}$ until the day of the assay. Oocytes underwent the TUNEL assay using the Fluorescein In Situ Cell Death Detection Kit (Boehringer Mannheim/Roche Diagnostics, Indianapolis, IN) according to Paula-Lopes and Hansen (2002).

\section{Statistical Analysis}

The statistical analysis was performed using SAS for Windows version 9.2 (SAS Institute Inc., Cary, NC). Continuous variables were evaluated for residual normality with the UNIVARIATE procedure and tested for homogeneity of variances with the Bartlett test. Variables that did not meet the ANOVA assumptions were base 10 logarithm $(\log 10 \mathrm{X})$, inverse $(1 / \mathrm{X})$, squared $\left(\mathrm{X}^{* *}-2\right)$, and square root $[\operatorname{SQRT}(\mathrm{X})]$ transformed. The dependent variables with normal distributions (parametric) were expressed as mean \pm SEM and analyzed as repeated measures using the MIXED procedure. The binomial variables were expressed as percentages and analyzed as repeated measures using 
the GLIMMIX procedure. The model for the analysis of parametric and binomial dependent variables included the effects of diet (1.7M and $\mathrm{M})$, genetic group (Bos indicus and Bos taurus), OPU (time), diet $\times$ genetic group interaction, diet $\times$ OPU interaction, genetic group $\times$ OPU interaction, and diet $x$ genetic group $x$ OPU interaction. The effect of the individual cows was included as the random effect. The correlation between BCS and RFAT was analyzed using the PROC CORR procedure, and the correlation model considered RFAT, weight, and BCS.

Relative gene expression analysis was performed using the REST software (Pfaffl et al., 2002) using the Pair-Wise Fixed Reallocation Randomization Test. The relative expression values are presented as the mean \pm SE. The mRNA levels of the genes were compared between energy levels, genetic groups, and energy levels within the genetic groups. The maintenance diet and Bos taurus oocyte data were used as a calibration group for the relative gene expression analysis.

\section{RESULTS}

\section{$B C S, B W$, and RFAT}

During the experimental period, high daily feed intake was observed ( $>95 \%$ ingestion) and there was no interaction between genetic groups and energy level $(P$ $=0.28)$ and $\operatorname{BCS}(P=0.23)$. The BCS $(P=0.001)$ and $\mathrm{BW}(P=0.001)$ were greater in the $1.7 \mathrm{M}$ group compared with the M group from d 30 to 44 of the experiment, respectively. The RFAT was greater in animals that received the $1.7 \mathrm{M} \operatorname{diet}(P=0.003)$ and in Bos indicus cows $(P=0.001)$. Additionally, an interaction effect was noted between genetic groups and diet for RFAT $(P=0.008)$ such that the increase in RFAT was greater in Bos indicus than in Bos taurus cows on the $1.7 \mathrm{M}$ diet. A positive correlation between BCS and RFAT was observed $(\mathrm{r}=0.85 ; P=0.0001)$; however, no correlation between RFAT and BW was seen $(\mathrm{r}=$ $0.02 ; P=0.69)$.

\section{Ovarian and Oocyte Evaluation}

For the total follicles visualized, no interaction was observed between the effects of the independent variables (diet, genetic groups and time; $P>0.05$ ) and no differences were noted between $\operatorname{diets}(P=0.55)$ and genetic groups $(P=0.44)$. The number of visible follicles between the first (26.6 \pm 3.1 follicles) and the last (21.6 \pm 1.9 follicles $)$ OPU sessions were similar $(P=0.26)$. For total oocyte recovery and recovery rate, there were no interactions $(P>0.05)$ between diet, genetic groups, and time, and the total number of recovered oocytes $(P$ $=0.74)$ and the recovery rates $(P=0.32)$ were similar $(P>0.05)$ between diets. However, the total number of recovered oocytes $(P=0.001)$ and recovery rates $(P=$ 0.001) were lower for Bos taurus donors (Table 3).

There were no interactive effects of the independent variables tested (genetic groups, diet, and time; $P>$ 0.05 ) on the oocyte quality index (Table 3). Additionally, oocyte quality and oocyte number as well as fragmentation rates (apoptosis) were similar $(P>0.05)$ between diets. However, Bos indicus cows produced more and better-quality viable oocytes than Bos taurus $(P<0.01)$. The DNA fragmentation rate was greater in Bos taurus cows $(P=0.004)$.

\section{In Vitro Embryo Production}

Only in vitro embryo production (IVP) data from 4 OPU sessions (third, fifth, sixth, and seventh OPU) were considered in the analyses due to contamination of the culture media during the other sessions. During those 4 OPU sessions, oocytes from abattoir ovaries were concomitantly cultured as controls, for which the cleavage rate was $63.9 \%$ and the blastocyst conversion rate was $30.8 \%$. Similar to the oocyte quality results, no interactive effects $(P>0.05)$ of diet, genetic group, and OPU were observed for the IVP results (Table 4). However, IVP was greater $(P<0.05$; Table 4$)$ in Bos indicus cows. Due to the pattern of blastocyst yields between the 2 diets throughout the 120-d experimental period, the IVP data were analyzed in 2 distinct periods (first period from 0 to $60 \mathrm{~d}$ and second period from $60 \mathrm{~d}$ until the end of the experiment, where d 0 was the first day that the diets were offered). There was a triple interaction effect between diet, genetic groups, and period on the IVP variables (Figure 2). In the Bos indicus cows that were fed the $1.7 \mathrm{M}$ diet, the blastocyst rate was lower in the second period. However, there was no effect of the $1.7 \mathrm{M}$ diet on the blastocyst rate of Bos taurus cows between the 2 periods.

\section{Transcript Quantification}

In the analyses of relative quantifications, the GAP$D H$ gene was used as the endogenous reference because of its lower coefficient of variation $(3.22 \%)$ between samples compared with that of $\beta$-actin (4.38\%). The HSP70.1, PRDX1, GLUT1, IGF1R, and IGF2R transcripts were detected in all samples. However, GLUT5 was exclusively detected in Bos taurus oocytes in both diet groups. The amount of this transcript was possibly negligible or even absent in the Bos indicus oocytes, so it was impossible for it to be detected by real-time 
¿ Table 3. Qualitative and quantitative oocytes (means \pm SEM) submitted at 9 ovum pick-up (OPU) of Bos indicus cows (Gir, $\mathrm{n}=14)$ and Bos taurus cows (Holstein, $\mathrm{n}=14)$ fed diets to meet $100 \%$ (maintenance) or $170 \%$ (high energy) of the energy required for maintenance

\begin{tabular}{|c|c|c|c|c|c|c|c|}
\hline \multirow[b]{2}{*}{ Item } & \multicolumn{2}{|c|}{ Diet } & \multicolumn{2}{|c|}{ Genetic group } & \multicolumn{3}{|c|}{$P$-value } \\
\hline & Maintenance & High energy & Bos indicus & Bos taurus & Diet & $\begin{array}{l}\text { Genetic } \\
\text { group }\end{array}$ & $\begin{array}{c}\text { Diet } \times \\
\text { genetic group }\end{array}$ \\
\hline No. of OPU & 126 & 126 & 126 & 126 & & & \\
\hline No. of follicles & $24.5 \pm 1,0$ & $25.2 \pm 1.3$ & $25.6 \pm 1.1$ & $24.2 \pm 1.1$ & 0.55 & 0.44 & 0.68 \\
\hline Total oocytes recovered & $18.6 \pm 1.4$ & $18.8 \pm 1.2$ & $22.8 \pm 1.5$ & $14.6 \pm 0.9$ & 0.74 & 0.001 & 0.72 \\
\hline Oocytes recovered/no. of follicles [\% (no./no.)] & $\begin{array}{c}75.5 \\
(2,306 / 3,053)\end{array}$ & $\begin{array}{c}74.7 \\
(2,353 / 3,152)\end{array}$ & $\begin{array}{c}88.8 \\
(2,846 / 3,205)\end{array}$ & $\begin{array}{c}60.4 \\
(1,813 / 3,000)\end{array}$ & 0.32 & 0.001 & 0.46 \\
\hline Viable oocytes & $14.6 \pm 1.1$ & $15.6 \pm 1.1$ & $19.3 \pm 1.2$ & $10.8 \pm 0.7$ & 0.49 & 0.001 & 0.92 \\
\hline Viable oocytes/total oocytes recovered [\% (no./no.)] & $\begin{array}{c}78.3 \\
(1,806 / 2,306)\end{array}$ & $\begin{array}{c}83.0 \\
(1,953 / 2,353)\end{array}$ & $\begin{array}{c}84.9 \\
(2,416 / 2,846)\end{array}$ & $\begin{array}{c}74.1 \\
(1,343 / 1,813)\end{array}$ & 0.18 & 0.001 & 0.78 \\
\hline No. of oocytes (quality) & & & & & & & \\
\hline Grade A & $3.19 \pm 0.35$ & $3.81 \pm 0.39$ & $5.32 \pm 0.44$ & $1.66 \pm 0.18$ & 0.17 & 0.001 & 0.91 \\
\hline Grade B & $7.10 \pm 0.52$ & $7.49 \pm 0.58$ & $9.55 \pm 0.62$ & $4.92 \pm 0.36$ & 0.53 & 0.001 & 0.45 \\
\hline Grade C & $4.38 \pm 0.43$ & $4.32 \pm 0.35$ & $4.46 \pm 0.44$ & $4.24 \pm 0.35$ & 0.88 & 0.68 & 0.37 \\
\hline Degenerate & $0.91 \pm 0.19$ & $0.82 \pm 0.12$ & $0.82 \pm 0.16$ & $0.90 \pm 0.15$ & 0.66 & 0.76 & 0.13 \\
\hline $\mathrm{OQI}^{\mathrm{I}}$ & $2.21 \pm 0.04$ & $2.20 \pm 0.04$ & $2.03 \pm 0.03$ & $2.37 \pm 0.04$ & 0.93 & 0.001 & 0.22 \\
\hline DNA fragmentation rate $\left(\mathrm{TUNEL}^{2}\right)[\%$ (nо./no.)] & $\begin{array}{l}29.3 \\
(27 / 92)\end{array}$ & $\begin{array}{l}26.2 \\
(28 / 107)\end{array}$ & $\begin{array}{l}16.6 \\
(21 / 117)\end{array}$ & $\begin{array}{l}40.6 \\
(34 / 82)\end{array}$ & 0.62 & 0.004 & 0.57 \\
\hline
\end{tabular}

${ }^{1}$ OQI $=$ Oocyte Quality Index $=($ grade $\mathrm{A} \times 1+$ grade $\mathrm{B} \times 2+$ grade $\mathrm{C} \times 3+$ Degenerate $\times 4) /$ total oocytes recovered. Modifed from Sales et al. $(2008)$.

${ }^{2}$ Terminal deoxynucleotidyl transferase mediated dUTP nick end labeling 


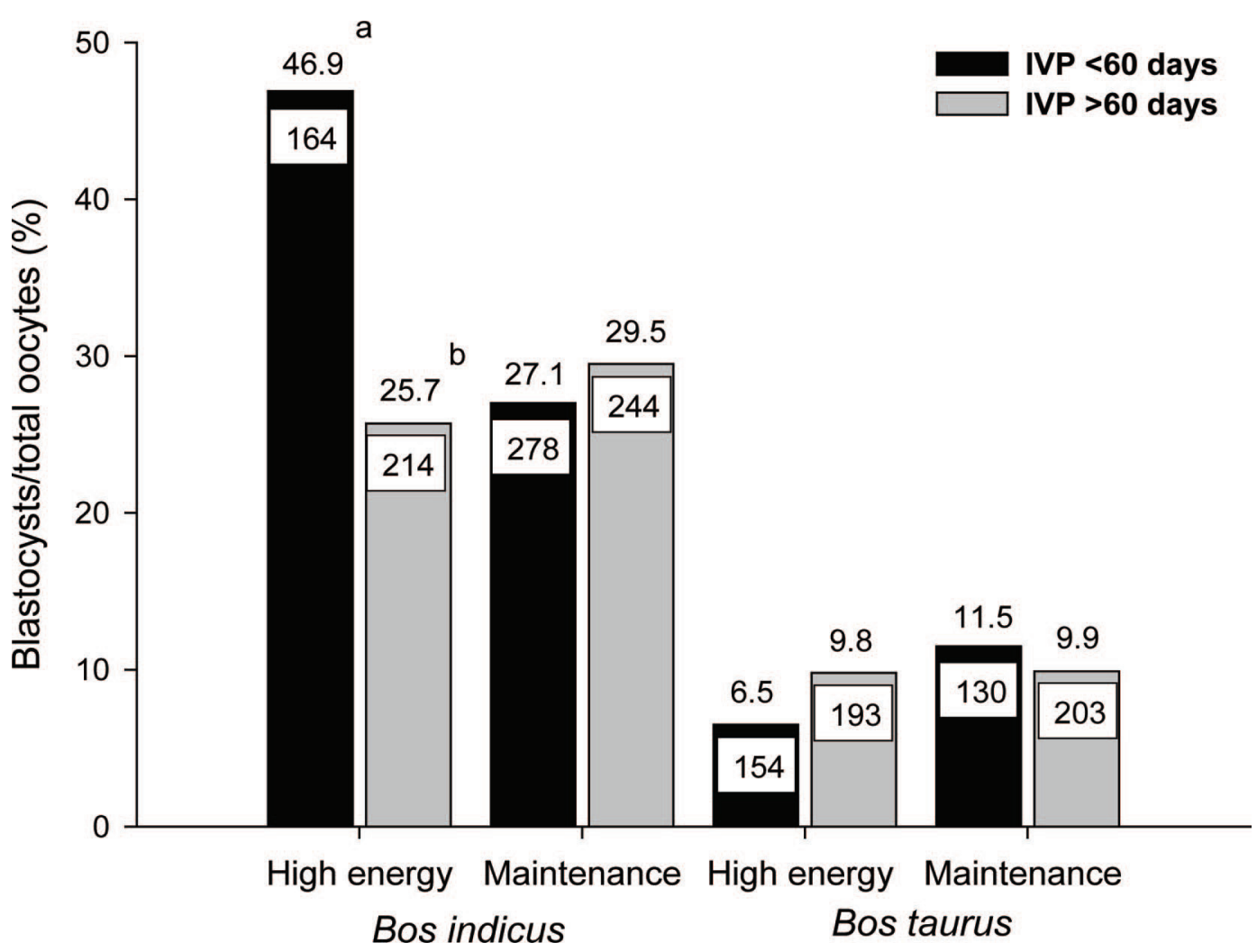

Figure 2. In vitro embryo production (IVP) of Bos indicus (Gir, $\mathrm{n}=14$ ) and Bos taurus (Holstein, $\mathrm{n}=14$ ) donors receiving high-energy diets (170\% of maintenance) or maintenance (100\% of maintenance) during the experimental period. Time $1=$ IVP up to $60 \mathrm{~d}$ after the beginning of the experiment; time $2=$ IVP $60 \mathrm{~d}$ after the beginning of the experiment. $P$-values were $P=0.21$ for diet, $P=0.01$ for genetic group, $P=0.24$ for time, $P=0.01$ for diet $\times$ genetic group interaction, and $P=0.01$ diet $\times$ genetic group $\times$ time interaction. Different letters $($ a,b) represent significant differences $(P=0.01)$; numbers inside bars are viable ooyctes.

PCR. It is important to emphasize that this technique is more sensitive and precise than conventional PCR (Bettegowda et al., 2006). Moreover, in the literature, there are reports of GLUT5 gene expression in Bos indicus oocytes and embryos (Camargo et al., 2005).

There was a lower abundance of IGF2R $(P=0.01)$ and HSP70.1 $(P=0.005)$ gene transcripts in oocytes from cows fed the higher energy diet. For the remaining genes (PRDX1, GLUT1, and IGF1R), transcript quantification was similar between diets. The GLUT1 $(P=0.001)$ and $\operatorname{IGF1R}(P=0.006)$ gene abundances were greater in Bos indicus cows, and for the other genes (HSP 70.1, PRDX1, and IGF2R) transcript quantification was similar between genetic groups. In the evaluation of the effects of diet within genetic groups, the abundances of most of the studied genes (HSP 70.1 , GLUT1, IGF1R, and IGF2R) were lower $(P=0.01)$ in the high-energy Bos indicus oocytes with the exception of PRDX1 (Figure 3). In Bos taurus, despite the identification of GLUT5 transcripts, no difference was observed between the diets, and similar results were observed for all of the other genes evaluated (Figure 3).

\section{Glucose and Insulin Concentrations}

There were no interaction effects of diet and genetic groups $(P=0.43)$ or genetic groups and time $(P=0.28)$ on glucose concentration, but there was an interaction effect between diet and time $(P=0.02$; Figure 4$)$ such that glucose increased during the experimental period in the cows fed the $1.7 \mathrm{M}$ diet and remained unaltered in the $\mathrm{M}$ diet cows $(P=0.01)$. Insulin concentrations were not affected by diet and genetic groups $(P=$ $0.13)$ or genetic groups and time $(P=0.28)$ interactions. However, an interactive effect was noted between time and diet on insulin $(P=0.001$; Figure 4$)$. Insulin concentrations increased throughout the experimental period in $1.7 \mathrm{M}$-fed cows but did not change in cows on the $\mathrm{M}$ diet. Additionally, glucose concentration was greater $(P=0.001)$ in Bos indicus cows $(73.7 \pm 0.7$ vs. 

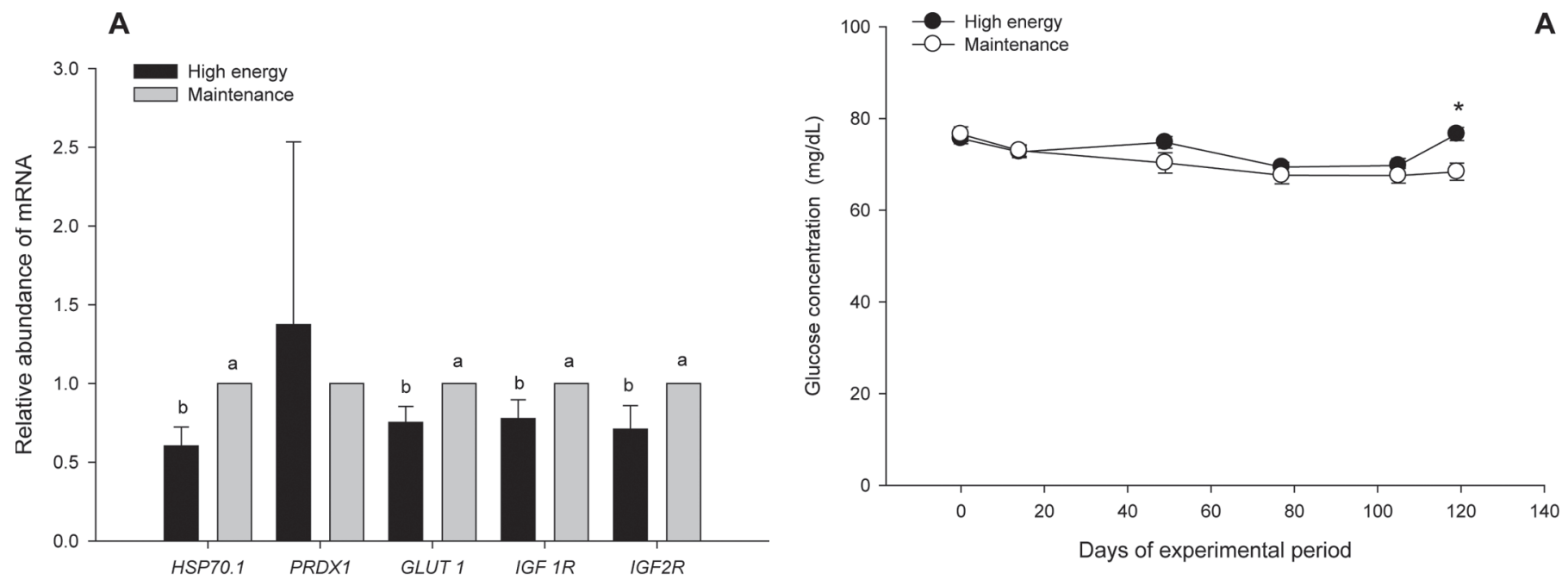

B
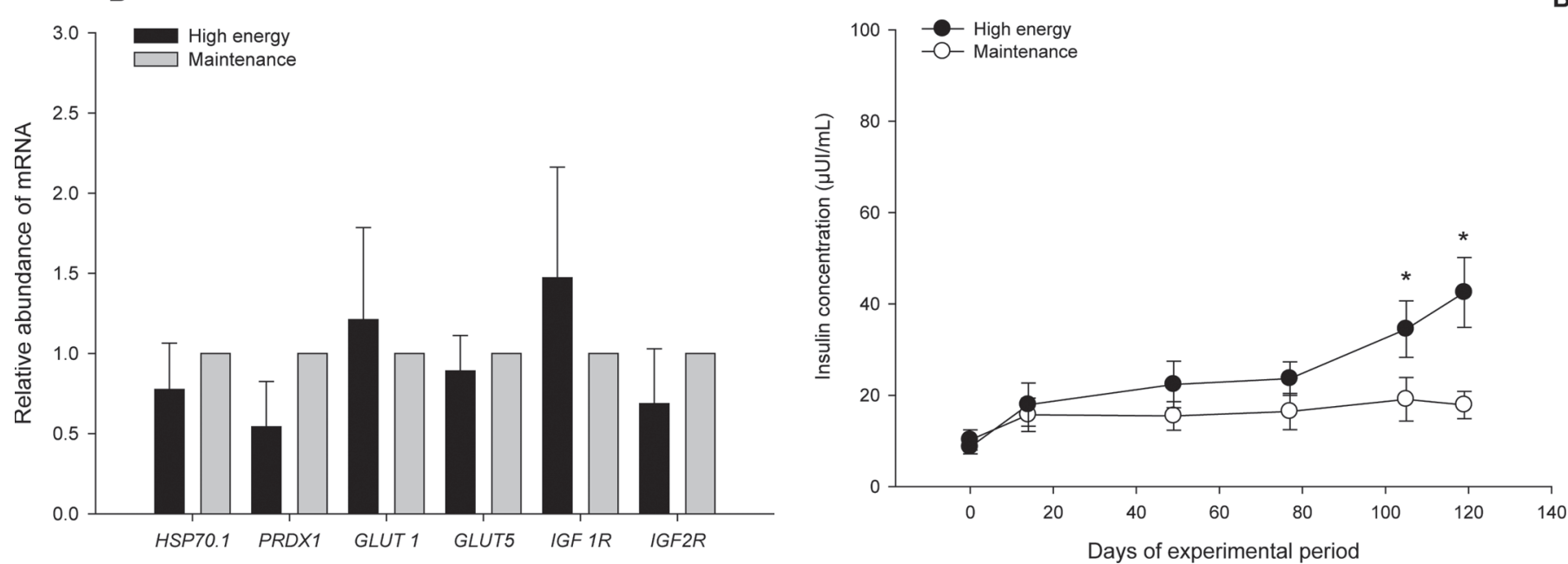

Figure 3. Relative abundance of transcripts (means \pm SEM) associated with cellular stress (PRDX1 and HSP 70.1$)$ and metabolism (GLUT1, IGF1R, and IGF2R) were obtained by real-time PCR of oocytes of Bos indicus (A) and Bos taurus cows (B) fed diets to meet $100 \%$ (maintenance, $\mathrm{n}=90$ ) or $170 \%$ (high energy, $\mathrm{n}=90$ ) of the energy required for maintenance. For both genetic groups, maintenance diet data were used as the calibration group $(\mathrm{n}=1)$ for the relative gene expression and means of high-energy group are shown as mean \pm SEM relative to the calibrator. Different letters $(\mathrm{a}, \mathrm{b})$ represent significant differences $(P=0.01)$.

$69.9 \pm 0.6 \mathrm{mg} / \mathrm{dL})$ as was insulin $(30.0 \pm 2.5$ vs $10.7 \pm$ $1.1 \mu \mathrm{IU} / \mathrm{mL}$ ) compared with the Bos taurus cows.

\section{GTT}

There was no interaction effect $(P>0.05)$ of diet and genetic groups on the GTT variables evaluated (Table 5). However, the basal glucose concentration was greater $(P=0.001)$ in the $1.7 \mathrm{M}$ diet cows than in the $\mathrm{M}$ cows, and basal glucose concentration was greater $(P=0.04)$ in the Bos indicus cows. Peak glu-

Figure 4. Serum concentrations of glucose (A) and insulin (B) in nonlactating cows fed diets to meet 100 (maintenance) or $170 \%$ (high energy) of the energy required for maintenance. Glucose $P$-values were $P=0.49$ for diet, $P=0.04$ for time, and $P=0.0001$ for $\operatorname{diet} \times$ time interaction; insulin $P$-values were $P=0.0001$ for diet, $P=0.0001$ for time, and $P=0.0001$ for diet $\times$ time interaction. An asterisk $\left(^{*}\right)$ means diet $\times$ time differ $(P<0.0001)$. Data are presented as means \pm SEM.

cose concentration after infusion was similar between diets $(P=0.29)$ and greater $(P=0.002)$ in Bos indicus cows. The glucose clearance rate $(k)$ was greater $(P=$ $0.06)$, and its half-life $\left(T^{1 / 2}\right)$ was lower $(P=0.06)$ in the $1.7 \mathrm{M}$ diet cows. The $k$ was greater $(P=0.002)$ and $T^{1 / 2}$ was lower $(P=0.002)$ in Bos taurus cows. The GTT glucose concentration curves are shown in Figure 5.

Before the glucose infusion, the basal concentration of insulin was greater in the $1.7 \mathrm{M}$ diet $(P=0.001)$ compared with the $\mathrm{M}$ diet and greater in Bos indicus $(P=0.001)$ than in Bos taurus cows. The basal insulin concentrations were $16.8 \pm 2.6(\mathrm{M})$ and $47.9 \pm 5.4$ 
Table 5. Glucose and insulin serum concentrations after i.v. infusion of sterile glucose solution at $0.3 \mathrm{~g} / \mathrm{kg}$ in Bos indicus cows (Gir, $\mathrm{n}=14$ ) and Bos taurus cows (Holstein, $\mathrm{n}=14$ ) fed diets to meet 100\% (maintenance) or $170 \%$ (high energy) of the energy required for maintenance

\begin{tabular}{|c|c|c|c|c|c|c|c|}
\hline \multirow[b]{2}{*}{ Item } & \multicolumn{2}{|c|}{ Diet } & \multicolumn{2}{|c|}{ Genetic group } & \multicolumn{3}{|c|}{$P$-value } \\
\hline & Maintenance & $\begin{array}{l}\text { High } \\
\text { energy }\end{array}$ & $\begin{array}{l}\text { Bos } \\
\text { indicus }\end{array}$ & Bos taurus & Diet & $\begin{array}{l}\text { Genetic } \\
\text { group }\end{array}$ & $\begin{array}{c}\text { Diet } \times \\
\text { genetic group }\end{array}$ \\
\hline Glucose basal level (mg/dL) & $65.9 \pm 0.9$ & $72.2 \pm 1.0$ & $67.7 \pm 1.1$ & $70.4 \pm 0.9$ & 0.001 & 0.04 & 0.64 \\
\hline Glucose peak level (mg/dL) & $238.6 \pm 8.4$ & $251.8 \pm 7.7$ & $262.7 \pm 6.9$ & $227.8 \pm 6.5$ & 0.29 & 0.002 & 0.85 \\
\hline Glucose clearance rate $(k)(\% / \mathrm{min})$ & $1.5 \pm 0.2$ & $1.8 \pm 0.2$ & $1.2 \pm 0.1$ & $2.1 \pm 0.2$ & 0.06 & 0.002 & 0.52 \\
\hline Glucose half-life $\left(T^{1 / 2}\right)(\min )$ & $56.9 \pm 6.2$ & $43.3 \pm 5.0$ & $59.7 \pm 4.1$ & $40.6 \pm 6.4$ & 0.06 & 0.002 & 0.53 \\
\hline$\Delta \operatorname{Max}^{1}(\mu \mathrm{IU} / \mathrm{mL})$ & $116.6 \pm 18.4$ & $174.1 \pm 16.3$ & $155.8 \pm 20.6$ & $134.9 \pm 17.0$ & 0.03 & 0.41 & 0.66 \\
\hline
\end{tabular}

${ }^{1}$ Insulin concentration peak over the baseline level.

$\mu \mathrm{IU} / \mathrm{mL}(1.7 \mathrm{M})$ in Bos indicus cows and $8.8 \pm 1.5(\mathrm{M})$ and $23.2 \pm 4.9 \mu \mathrm{IU} / \mathrm{mL}(1.7 \mathrm{M})$ in Bos taurus cows. Moreover, the insulin peak and increase $(\Delta$ Max $)$ after the glucose infusion was greater in cows fed with the $1.7 \mathrm{M}$ diet. In spite of the greater basal insulin concentrations in the Bos indicus cows $(P>0.05)$, no differences in peak insulin were seen between the genetic groups following glucose infusion. Glucose and insulin concentrations remained elevated in Bos indicus cows for up to 120 min after glucose infusion, whereas in Bos taurus cows the glucose and insulin concentrations returned to near basal concentrations within $80 \mathrm{~min}$ of the glucose infusion. The GTT insulin concentration curves are shown in Figure 5.

\section{DISCUSSION}

To our knowledge, ours is the first study of the effects of excess energy on IVP in 2 distinct genetic groups (Bos indicus and Bos taurus) with expected differences in reproduction. After a long period on a high-energy diet, a reduction in the IVP and an alteration of the gene expression in Bos indicus cows was observed. Additionally, Bos indicus cows had better quality and greater numbers of oocytes as well as greater IVP than Bos taurus cows. These results only partially confirm the experimental hypothesis, as the deleterious effect of dietary energy only occurred in Bos indicus cows.

Feed intake and BW gain results indicated that the amount of energy offered was enough to promote a considerable increase in subcutaneous fat, BW, and BCS in both genetic groups. Thus, the excess energy supplied during the trial may have been sufficient to promote the metabolic and endocrine changes necessary to modify the reproductive performance of the donors, as reported previously (Leroy et al. 2008; Rooke et al., 2009).

The excessive-energy diet reduced blastocyst rate in Bos indicus cows only after $60 \mathrm{~d}$ of exposition as indicated by the genetic groups $\times$ diet $\times$ period interaction. This impaired blastocyst rate remained low until the end of the study. Conversely, no effect of the prolongued exposure to high dietary energy on IVP was observed in Bos taurus cows. However, it is important to emphasize that the diets in the present study were formulated based on the requirements of Holstein cows; this may have biased the results, as the maintenance needs for Gir cows are different from Bos taurus cows due to distinct energy requirements and feed conversion efficiency. However, no information is available regarding maintenance needs for Gir cows.

A hyperinsulinemic state was observed in the cows on the high-energy diet at the end of the experimental period, suggesting a cumulative effect of the nutritional plane on fertility that was similar to that found in the literature (Adamiak et al., 2005). Moreover, in the cows fed the high-energy diet, a peripheral resistance to insulin was observed, as evidenced by the GTT. The basal concentration of insulin was greater in Bos indicus cows fed the high-energy diet. Additionally, the required insulin production to control the infused glucose was greater in high-energy groups, characterizing the peripheral insulin resistance.

Although the intrinsic mechanisms involved in the lowering of oocyte quality caused by excess energy are unknown, some authors have attributed negative IVP results to the excess insulin because no alterations were found in the concentrations of the other studied hormones, such as IGF-1 and leptin (Adamiak et al., 2005). However, leptin and local growth factors are involved in mechanisms through which diet may affect oocyte quality (Webb et al., 2004). Moreover, adequate IGF-I concentrations are important for follicular growth and oocyte maturation (Landau et al., 2000), because excessive bioavailable IGF-I reduces oocyte competence (Armstrong et al., 2002). Insulin concentrations in hyperinsulinemic Bos indicus cows were similar to those reported by Adamiak et al. (2005) in Bos taurus 

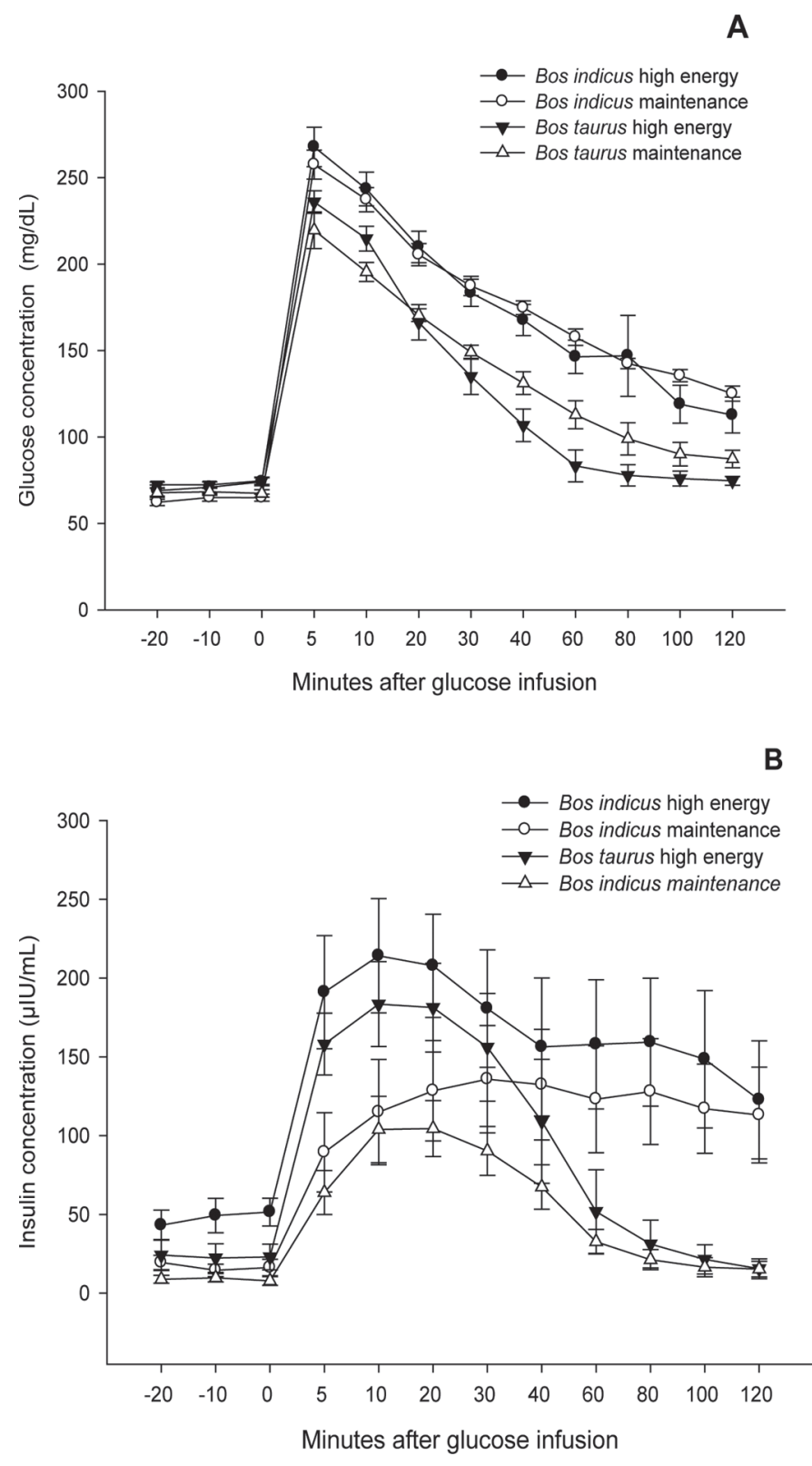

Figure 5. Serum concentrations of glucose (A) and insulin (B) after i.v. infusion of sterile glucose solution at $0.3 \mathrm{~g} / \mathrm{kg}$ of Bos indicus cows (Gir; $n=14$ ) and Bos taurus cows (Holstein; $n=14$ ) fed diets to meet 100 (maintenance) or $170 \%$ (high energy) of the energy required for maintenance. Data are presented as means \pm SEM.

$(58.0 \mu \mathrm{IU} / \mathrm{mL})$ and in women with polycystic ovaries (40 to $52 \mu \mathrm{IU} / \mathrm{mL}$; Dunaif, 1997). Long exposure to a high-dietary energy diet (>60 d) seems to be necessary to deleteriously affect oocyte quality. Some studies have demonstrated that chronically hyperinsulinemic animals develop peripheral insulin resistance that compromises the glucose uptake mechanism, which leads to cellular apoptosis (Pantaleon and Kaye, 1996; Chi et al., 2000). Furthermore, excess energy alters the expres- sion of genes linked to glucose metabolism and oxidative stress (superoxide dismutase), which may interfere with oocyte quality (Wrenzycki et al., 2001). Low-IVP yielding Bos indicus cows showed downregulation of glucose transport regulatory proteins and the IGF-I receptor system. The expression of GLUT1 appears to be essential for the oocyte maturation process (Zhou et al., 2000). Additionally, the high insulin and IGF-1 concentrations promoted by the ingestion of a highenergy diet may be responsible for the reduced expression of genes linked to cellular metabolism (Armstrong et al., 2001).

In vitro embryo production was related to the genetic groups; specifically, IVP was greater in Bos indicus cows, which is supported by the literature (Camargo et al., 2007; Gimenes et al., 2014). The lower IVP in Bos taurus cows was linked to a lower fertilization rate, a reduction in developmental capacity after fecundation, and a lower oocyte resistance to stress (Paula-Lopes et al., 2003; Hansen, 2004; Camargo et al., 2007). Furthermore, cell metabolism-linked genes (GLUT1 and IGF1R) were more abundant in Bos indicus cows. These findings may explain, in part, the differences in oocyte quality and IVP between Bos indicus and Bos taurus because the presence of these glucose transport regulatory proteins in the cell is important for glucose uptake and, consequently, cellular energy metabolism overall (Zhou et al., 2000; Sinclair et al., 2003; Frolova and Moley, 2011). Oocyte recovery was greater in Bos indicus cows, but the number of oocytes recovered from the different genetic groups was greater than those reported in the literature (Holstein: 4-7, Merton et al., 2009; Gir: 7-15, Viana et al., 2010; de S Torres Júnior et al., 2008). Such differences may be attributed to the previous method of cow selection (from a total of 24 cows in the pre-experimental period, 14 were selected), which prioritized cows with higher visible follicle counts from 2 evaluations performed $10 \mathrm{~d}$ apart. Furthermore, cows were synchronized so that aspirations took place at the onset of a wave emergence, thereby avoiding the presence of a corpus luteum or a dominant follicle (Lansbergen et al., 1995). The presence of a corpus luteum reduces the ovarian area available for follicular development and hampers follicular aspiration (Viana et al., 2010).

In contrast to the literature (Nolan et al., 1998; Yaakub et al., 1999; Armstrong et al., 2001), the oocyte and embryo qualities were similar between diets in our study. Although the experimental design did not permit conclusions related to changes in the uterine environment, the effect of high dietary energy on oocyte and embryo quality observed in other studies may have been influenced by alterations at the level of the oviduct and the uterus that compromised oocyte quality and 
early embryo development (Lane and Bavister, 1999). Oocyte quality was greater in Bos indicus cows, and similar results have been reported in heifers (Gimenes et al., 2014) and cows (Pontes et al., 2010) subjected to follicular aspiration. In those studies, oocyte quality was lower in Bos taurus (Holsteins) than in Bos indicus cows (Nelore: Gimenes et al., 2014; Gir: Pontes et al., 2010). One of the possible explanations for the observed genetic differences with respect to oocyte quality could be the greater IGF-1 concentrations in Bos indicus (Brahman: $41 \pm 6 \mathrm{ng} / \mathrm{mL}$ ) compared with Bos taurus cows (Angus: $19 \pm 6 \mathrm{ng} / \mathrm{mL}$ ); such an association has been observed elsewhere (Simpson et al., 1994).

The experimental diets did not interfere with the number of visible follicles. In contrast, some reports state that high DMI may increase (Gong et al., 2002) or even decrease the number of recruited follicles in each growth wave (Sartori et al., 2007). In spite of the individual effects on the number of recruited follicles per wave (Burns et al., 2005), the pre-experimental ultrasound evaluations allowed the groups to be closely balanced in terms of the visible antral follicles present in the ovaries. Moreover, due to the high repeatability and predictability of the follicular population (Boni et al., 1997), the eventual variations in the number of recruited follicles during the trial were very likely to have resulted from the treatments. Consecutive follicular aspirations did not influence the number of follicles present in the ovaries. This result was not observed in a previous trial (de S Torres Júnior et al., 2008), in which a gradual decline in the number of visible follicles and oocytes was observed in Bos indicus cows after 24 consecutive OPU at 7 -d intervals. These differences were likely due to the shorter interval $(7 \mathrm{~d})$ between OPU sessions compared with the 14-d interval used in the present study.

Successive follicular aspirations promote mechanical damage, which leads to alterations to the ovarian parenchyma (degeneration, fibrosis, or adherences; Viana et al., 2003), oocyte steroidogenesis, and metabolic changes (increase of local inflammatory factors; Petyim et al., 2001). Our findings are relevant because they ensured that a 14-d interval between OPU did not result in reducing the number of recruited follicles (15 to 25) in the subsequent waves. Additionally, the number of follicles present in the ovary is another factor that may influence OPU yield. It has been reported that there was no reduction in the number of visible follicles and recovered oocytes in low-follicular-count cows subjected to OPU every $3 \mathrm{~d}$ (Boni et al., 1997). In contrast, in Nelore (Bos indicus) cows, in which the antral follicle count is generally high ( $>30$ follicles), successive OPU sessions at 14-d intervals (6 OPU) reduced subsequent OPU yields (Gimenes et al., 2014). This difference in the response of cows with high- and low-visible follicle counts could be a consequence of the greater risk of ovarian lesions in cows submitted to repeated ovarian aspirations (Viana et al., 2003).

In conclusion, different dietary energy levels did not influence the oocyte numbers and quality. However, the intake of a high-energy diet for a long period reduced the IVP in Bos indicus cows by causing a hyperinsulinemic state and promoting the downregulation of cellular metabolism genes. Oocyte quality and IVP were greater in Bos indicus compared with Bos taurus.

\section{ACKNOWLEDGMENTS}

We acknowledge the financial support from Fundação de Amparo à Pesquisa do Estado de São Paulo (FAPESP; Sãp Paulo, Brazil; Proc. 2008/08508-5) and Coordenação de Aperfeiçoamento de Pessoal de Nível Superior (CAPES; Brasilia, Brazil), the cooperation and assistance of the EMBRAPA (Juiz de Fora, MG, Brazil) company to conduct this study, and the follicular aspiration material donation from WTA (Cravinhos, SP, Brazil).

\section{REFERENCES}

Adamiak, S. J., K. Mackie, R. G. Watt, R. Webb, and K. D. Sinclair. 2005. Impact of nutrition on oocyte quality: Cumulative effects of body composition and diet leading to hyperinsulinemia in cattle. Biol. Reprod. 73:918-926.

Andersen, A. S., T. Kjeldsen, F. C. Wiberg, H. Vissing, L. Schäffer, J. S. Rasmussen, P. De Meyts, and N. P. Moller. 1992. Identification of determinants that confer ligand specificity on the insulin receptor. J. Biol. Chem. 267:13681-13686.

Armstrong, D. G., G. Baxter, C. O. Hogg, and K. J. Woad. 2002. Insulin-like growth factor (IGF) system in the oocyte and somatic cells of bovine preantral follicles. Reproduction 123:789-797.

Armstrong, D. G., J. G. Gong, and R. Webb. 2003. Interactions between nutrition and ovarian activity in cattle: physiological, cellular, and molecular mechanisms. Reprod. Suppl. 61:403-414.

Armstrong, D. G., T. G. Mcevoy, G. Baxter, J. J. Robinson, C. O. Hogg, K. J. Woad, R. Webb, and K. D. Sinclair. 2001. Effect of dietary energy and protein on bovine follicular dynamics and embryo production in vitro: Associations with the ovarian insulin-like growth factor system. Biol. Reprod. 64:1624-1632.

Bertolini, M., S. W. Beam, H. Shim, L. R. Bertolini, A. L. Moyer, T. R. Famula, and G. B. Anderson. 2002. Growth, development and gene expression by in vivo- and in vitro-produced day 7 and 16 bovine embryos. Mol. Reprod. Dev. 63:318-328.

Bettegowda, A., O. V. Patel, and J. J. Ireland. 2006. Quantitative analysis of messenger RNA abundance for ribosomal protein L-15, cyclophilin-A, phosphoglycerokinase, beta-glucuronidase, glyceraldehyde 3-phosphate dehydrogenase, beta-actin, and histone $2 \mathrm{a}$ during bovine oocyte maturation and early embryogenesis in vitro. Mol. Reprod. Dev. 73:267-278.

Boni, R., M. W. M. Roelofsen, M. C. Pieterse, J. Kogut, and T. A. Kruip. 1997. Follicular dynamics, repeatability and predictability of follicular recruitment in cows undergoing repeated follicular puncture. Theriogenology 48:277-289.

Burns, D. S., F. Jimenez-Krassel, J. L. H. Ireland, P. G. Knight, and J. J. Ireland. 2005. Numbers of antral follicles during follicular waves in cattle: evidence for high variation among animals, very high repeatability in individuals, and an inverse association with 
serum follicle-stimulating hormone concentrations. Biol. Reprod. $73: 54-62$.

Camargo, L. S. A., A. M. Powell, V. R. Filho, and R. J. Wall. 2005 Comparison of gene expression in individual preimplantation bovine embryos produced by in vitro fertilisation or somatic cell nuclear transfer. Reprod. Fertil. Dev. 17:487-496.

Camargo, L. S., J. H. M. Viana, A. A. Ramos, R. V. Serapião, W. F. Sa, A. M. Ferreira, M. F. M. Guimarães, and V. R. Vale Filho. 2007. Developmental competence and expression of the Hsp 70.1 gene in oocytes obtained from Bos indicus and Bos taurus dairy cows in a tropical environment. Theriogenology 68:626-632.

Chi, M. M. Y., A. L. Schlein, and K. H. Moley. 2000. High insulin-like growth factor 1 (IGF-1) and insulin concentrations trigger apoptosis in the mouse blastocyst via down-regulation of the IGF-1 receptor. Endocrinology 141:4784-4792.

de S Torres Júnior, J. R., M. F. A. Pires, W. F. Sá, A. M. Ferreira, J. H. M. Viana, L. S. A. Camargo, A. A. Ramos, I. M. Folhadella, J. Polisseni, C. Freitas, C. A. A. Clemente, M. F. de Sá Filho, F. F. P. Lopes, and P. S. Baruselli. 2008. Effect of maternal heat-stress on follicular growth and oocyte competence in Bos indicus cattle. Theriogenology 69:155-166.

Dunaif, A. 1997. Insulin resistance and the polycystic ovary syndrome: Mechanism and implications for pathogenesis. Endocr. Rev. 18:774-800.

Frolova, A. I., and K. H. Moley. 2011. Glucose transporters in the uterus: an analysis of tissue distribution and proposed physiological roles. Reproduction 142:211-220.

Garnsworthy, P. C., A. Lock, G. E. Mann, K. D. Sinclair, and R. Webb. 2008. Nutrition, metabolism, and fertility in dairy cows: 1 . Dietary energy source and ovarian function. J. Dairy Sci. 91:3814-3823.

Gimenes, L. U., M. L. Ferraz, P. F. Neto, M. R. Chiaratti, L. G. Mesquita, M. F. Sá Filho, F. V. Meirelles, L. A. Trinca, F. P. Rennó, Y. F. Watanabe, and P. S. Baruselli. 2014. The interval between the emergence of pharmacologically synchronized ovarian follicular waves and ovum pickup does not significantly affect in vitro embryo production in Bos indicus, Bos taurus, and Bubalus bubalis. Theriogenology . In press.

Gong, J. G., W. J. Lee, P. C. Garnsworthy, and R. Webb. 2002. Effect of dietary-induced increases in circulating insulin concentrations during the early postpartum period on reproductive function in dairy cows. Reproduction 123:419-427.

Gordon, I. 2004. Laboratory Production of Cattle Embryos. 1st ed Cambridge Univ. Press, London, UK.

Hansen, P. J. 2004. Physiological and cellular adaptations of zebu cattle to thermal stress. Anim. Reprod. Sci. 82-83:349-360.

Kawarsky, S. J., and W. King. 2001. Expression and localisation of heat shock protein 70 in cultured bovine oocytes and embryos. Zygote 9:39-50.

Landau, S., R. Braw-Tal, M. Kaim, A. Bor, and I. Bruckental. 2000. Preovulatory follicular status and diet affect the insulin and glucose content of follicles in high-yielding dairy cows. Anim. Reprod. Sci. 64:181-197.

Lane, M., and B. D. Bavister. 1999. Regulation of intracellular pH in bovine oocytes and cleavage stage embryos. Mol. Reprod. Dev. 54:396-401.

Lansbergen, L. M. T. E., A. M. Van Wagtendonk-de Leeuw, J. H. G. den Dass, L. de Ruigh, G. van der Streek, and J. M. C. Reinders. 1995. Factors affecting ovum-pick up in cattle. Theriogenology 43:259 (Abstr.)

Leibfried, L., and N. L. First. 1979. Characterization of bovine follicular oocytes and their ability to mature in vitro. J. Anim. Sci. 48:76-86

Leroy, J. L. M. R., G. Van Soom, G. Opsomer, I. G. F. Goovaerts, and P. E. J. Bols. 2008. Reduced fertility in high-yielding dairy cows: Are the oocyte and embryo in danger? Part II. Mechanisms linking nutrition and reduced oocyte and embryo quality in high-yielding dairy cows. Reprod. Domest. Anim. 43:623-632.

Leyens, G., B. Knoops, and I. Donnay. 2004. Expression of peroxiredoxins in bovine oocytes and embryos produced in vitro. Mol. Reprod. Dev. 69:243-251.
Merton, J. S., B. Ask, D. C. Onkundi, E. Mullaart, B. Colenbrander, and M. Nielen. 2009. Genetic parameters for oocyte number and embryo production within a bovine ovum pick-up-in vitro production embryo-production program. Theriogenology 72:885-893.

Mourot, M., I. Dufort, C. Gravel, O. Algriany, S. Dieleman, and M. A. Sirard. 2006. The influence of follicle size, FSH-enriched maturation medium, and early cleavage on bovine oocyte maternal mRNA levels. Mol. Reprod. Dev. 73:1367-1379.

NRC. 2001. Nutrient Requirements of Dairy Cattle. 7th rev. ed. Natl. Acad. Press, Washington, DC.

Niemann, H., and C. Wrenzycki. 2000. Alterations of expression of developmentally important genes in preimplantation bovine embryos by in vitro culture conditions: implications for subsequent development. Theriogenology 53:21-34.

Nolan, R., P. Duf, M. Wade, D. O'Callaghan, and M. P. Boland. 1998 Effect of quantity and type of diet and frequency of trans-vaginal ovum aspiration on in vitro embryo development in heifers. Theriogenology 49:402.

Opsomer, G., T. H. Wensing, H. Laevens, M. Coryn, and A. De Kruif. 1999. Insulin resistance: the link between metabolic disorders and cystic ovarian disease in high yielding dairy cows? Anim. Reprod. Sci. 56:211-222.

Pantaleon, M., and P. L. Kaye. 1996. IGF-I and insulin regulate glucose transport in mouse blastocysts via IGF-I receptor. Mol. Reprod. Dev. 44:71-76.

Paula-Lopes, F. F., C. C. Chase Jr., Y. M. Al-Katanani, C. E. Krininger, R. M. Rivera, S. Tekin, A. C. Majewski, O. M. Ocon, T. A. Olson, and P. J. Hansen. 2003. Genetic divergence in cellular resistance to heat shock in cattle: Differences between breeds developed in temperate versus hot climates in responses of preimplantation embryos, reproductive tract tissues and lymphocytes to increased culture temperatures. Reproduction 125:285-294.

Paula-Lopes, F. F., and P. J. Hansen. 2002. Apoptosis is an adaptative response in bovine preimplantation embryos that facilitates survival after heat shock. Biochem. Biophys. Res. Commun. 295:37-42.

Petyim, S., R. G. E. Bá, M. Forsberg, H. Rodríguez-Martínez, and B. Larsson. 2001. Effects of repeated follicular punctures on ovarian morphology and endocrine parameters in dairy heifers. J. Vet. Med. A Physiol. Pathol. Clin. Med. 48:449-463.

Pfaffl, M. W., G. W. Horgan, and L. Dempfle. 2002. Relative expression software tool (REST) for group-wise comparison and statistical analysis of relative expression results in real-time PCR Nucleic Acids Res. 30:e36.

Pontes, J. H. F., K. C. F. Silva, A. C. Basso, A. G. Rigo, C. R. Ferreira, G. M. G. Santos, B. V. Sanches, J. P. F. Porcionato, P. H. S. Vieira, F. S. Faifer, F. A. M. Sterza, J. L. Schenk, and M. M. Seneda. 2010. Large-scale in vitro embryo production and pregnancy rates from Bos taurus, Bos indicus, and indicus-taurus dairy cows using sexed sperm. Theriogenology 74:1349-1355.

Ramakers, C., J. M. Ruijter, R. H. Deprez, and A. F. Moorman. 2003. Assumption-free analysis of quantitative real-time polymerase chain reaction (PCR) data. Neurosci. Lett. 339:62-66.

Reimers, T. J., R. G. Cowan, J. P. Mccann, and M. W. Ross. 1982. Validation of a rapid solid-phase radioimmunoassay for canine, bovine, and equine insulin. Am. J. Vet. Res. 43:1274-1278.

Rooke, J. A., A. Ainslie, R. G. Watt, F. M. Alink, T. G. Mcevoy, K. D. Sinclair, P. C. Garnsworthy, and R. Webb. 2009. Dietary carbohydrates and amino acids influence oocyte quality in dairy heifers. Reprod. Fertil. Dev. 21:419-427.

Sagirkaya, H., M. Misirlioglu, A. Kaya, N. L. First, J. J. Parrish, and E. Memili. 2006. Developmental and molecular correlates of bovine preimplantation embryos. Reproduction 131:895-904.

Sales, J. N. S., L. M. K. Dias, A. T. M. Viveiros, M. N. Pereira, and J. C. Souza. 2008. Embryo production and quality of Holstein heifers and cows supplemented with betacarotene and tocopherol. Anim. Reprod. Sci. 106:77-89.

Sales, J. N. S., R. V. V. Pereira, R. C. Bicalho, and P. S. Baruselli 2011. Effect of injectable copper, selenium, zinc and manganese on the pregnancy rate of crossbred heifers (Bos indicus $\times$ Bos taurus) synchronized for timed embryo transfer. Livest. Sci. 142:59-62. 
Santos, J. E., R. L. Cerri, and R. Sartori. 2008. Nutritional management of the donor cow. Theriogenology 69:88-97.

Sartori, R., M. R. Bastos, P. S. Baruselli, L. U. Gimenes, R. L. Ereno, and C. M. Barros. 2010. Physiological differences and implications to reproductive management of Bos taurus and Bos indicus cattle in a tropical environment. Soc. Reprod. Fertil. Suppl. 67:357-375.

Sartori, R., M. R. Bastos, M. R. Mollo, and A. C. Martins. 2007. Influência da ingestão alimentar na produção de embriões bovinos. Acta Scientiae Veterinariae 35:869-873.

Schäffer, L. 1994. A model for insulin binding to the insulin receptor. Eur. J. Biochem. 221:1127-1132.

Simpson, R. B., C. C. Chase, L. J. Spicer, R. K. Vernon, A. C. Hamond, and D. O. Rae. 1994. Effect of exogenous insulin on plasma and follicular insulin-like growth factor I, insulin-like growth factor binding protein activity, follicular estradiol and progesterone, and follicular growth in superovulated Angus and Brahman cows. J. Reprod. Fertil. 102:483-492.

Sinclair, K. D., J. A. Rooke, and T. G. McEvoy. 2003. Regulation of nutrient uptake and metabolism in pre-elongation ruminant embryos. Reprod. Suppl. 61:371-385.

Thatcher, W., J. E. Santos, and C. R. Staples. 2011. Dietary manipulations to improve embryonic survival in cattle. Theriogenology 76:1619-1631.

Trinder, P. 1969. Determination of glucose in blodd using glucose oxidase with an alternative oxygen acceptor. Ann. Clin. Biochem. $6: 24-26$.

Viana, J. H. M., A. A. Nascimento, N. L. Pinheiro, A. M. Ferreira, L. S. A. Camargo, W. F. Sá, and A. P. Marques Júnior. 2003. Carac- terização de sequelas subsequentes à punção folicular em bovinos. Pesqui. Vet. Bras. 23:119-124.

Viana, J. H. M., M. P. Palhao, L. G. B. Siqueira, J. F. Fonseca, and L. S. A. Camargo. 2010. Ovarian follicular dynamics, follicle deviation, and oocyte yield in Gyr breed (Bos indicus) cows undergoing repeated ovum pick-up. Theriogenology 73:966-972.

Webb, R., P. C. Garnsworthy, J. G. Gong, and D. G. Armstrong. 2004. Control of follicular growth: local interactions and nutritional influences. J. Anim. Sci. 82(E. Suppl.):E63-E74.

Wildman, E. E., G. M. Jones, P. E. Wagner, R. L. Boman, J. R. Troutt, and T. N. Lesch. 1982. A dairy cow body condition scoring system and its relationship to selected production charactristics. J. Dairy Sci. 65:495-501.

Wilson, C. M., Y. Mitsumoto, F. Maher, and A. Klip. 1995. Regulation of cell surface GLUT1, GLUT3, and GLUT4 by insulin and IGF-I in L6 myotubes. FEBS Lett. 368:19-22.

Wilson, D. E. 1992. Aplication of ultrasound for genetic improvement. J. Anim. Sci. 70:973-983.

Wrenzycki, C., D. Herrmann, L. Keskintepe, A. Martins, S. Sirisathien, and B. Brackett. 2001. Effects of culture system and protein supplementation on mRNA expression in pre-implantation bovine embryos. Hum. Reprod. 16:893-901.

Yaakub, H., D. O'Callaghan, and M. P. Boland. 1999. Effect of type and quantity of concentrates on superovulation and embryo yield in beef heifers. Theriogenology 51:1259-1266.

Zhou, J., M. Bievre, and C. A. Bondy. 2000. Reduced GLUT1 expression in Igf1-/ - null oocytes and follicles. Growth Horm. IGF Res. 10:111-117. 